\section{Revised magnetic polarity time scale for Late Cretaceous and Cenozoic time}

\begin{abstract}
A revision of the Heirtzler and others magnetic reversal time scale is presented. In addition to incorporating published studies which have increased the resolution and accuracy of their time scale, we have revised the relative lengths of anomalies $4 A$ to 5 and 29 to 34 and have eliminated anomaly 14 . We have calibrated the time scale by choosing an age of $3.32 \mathrm{~m} . \mathrm{y}$. B.P. for the older reversal boundary of anomaly $2 \mathrm{~A}$ and 64.9 m.y. B.P. for the older reversal boundary of anomaly 29 . The resulting magnetic reversal time scale is in reasonable agreement with the biostratigraphic ages from Deep Sea Drilling Project (DSDP) drill holes.
\end{abstract}

\section{INTRODUCTION}

The Heirtzler and others (1968) magnetic reversal time scale was derived by assuming that magnetic anomaly profiles above the ocean ridges and basins were manifestations of earlier reversals in the polarity of the Earth's magnetic field, as hypothesized by Vine and Matthews (1963). The scale derived its resolution from magnetic anomaly profiles over the relatively rapid sea-floor spreading system in the North Pacific and its linearity from the assumption of a constant rate of sea-floor spreading since Late Cretaceous time in the South Atlantic. Dates were assigned to the magnetic reversal time scale by extrapolation from a date of 3.35 m.y. for the older reversal boundary of anomaly $2 \mathrm{~A}$ correlated to the Gauss-Gilbert magnetic polarity epoch boundary. The resulting magnetic time scale assigned an age slightly younger than the Cretaceous-Tertiary boundary to the causative body of anomaly 26 .

Since the appearance of the Heirtzler and others (1968) magnetic reversal time scale, several studies of marine magnetic anomalies have attempted to improve the resolution of certain segments of the reversal pattern. More recently, work in the magnetic stratigraphy of an Upper Cretaceous to Paleocene section near Gubbio, Italy, has shown that the Cretaceous-Tertiary boundary occurs just below a normally magnetized zone correlated with marine magnetic anomaly 29 (Lowrie and others, 1976; Alvarez and others, 1977). This additional datum makes it possible to recalibrate the Cenozoic magnetic polarity time scale by interpolation.

This report presents a revised magnetic reversal time scale
John L. LaBrecque

Lamont-Doherty Geological Observatory and Department of Geological Sciences

Columbia University

Palisades, New York 10964

Dennis $V$. Kent

Lamont-Doherty Geological Observatory

Palisades, New York 10964

Steven C. Cande

Lamont-Doherty Geological Observatory and

Department of Geological Sciences

Columbia University

Palisades, New York 10964 that incorporates this recalibration as well as various studies that have increased the accuracy of the relative durations of the magnetic polarity intervals. The age of oceanic basement predicted by the revised magnetic reversal time scale is then compared to the biostratigraphically derived age of the overlying sediment obtained from studies of DSDP drill holes.

It should be noted that for the sake of brevity we will speak of the Vine and Matthews type of marine magnetic anomalies as synonymous with their causative magnetized basement rocks. We will also follow the convention of assigning Late Cretaceous and Cenozoic marine magnetic anomaly numbers to anomalies formed during periods of predominantly normal geomagnetic field polarity.

\section{METHOD: MAGNETIC TIME SCALE AND CALIBRATION}

The initial step was to review the literature for modifications of the Heirtzler and others (1968) time scale that we felt were supported by the observed marine magnetic anomaly pattern. We included many of the modifications of Talwani and others (1971), McKenzie and Sclater (1971), Larson and Pitman (1972), Blakely and Cox (1972), Blakely (1974), and Schlich (1975) which were designed to improve the accuracy and resolution of the magnetic reversal pattern. Implicit in these modifications was the assumption of a constant rate of sea-floor spreading in the South Atlantic, which Heirtzler and others (1968) used originally to date the sequence of magnetic reversals. In comparing the relative lengths 
of the resulting synthetic magnetic anomaly pattern to observed profiles from the Pacific, Indian, and Atlantic Oceans, we found certain discrepancies which required revision as follows.

1. The sequence of apparent reversals originally named anomaly 14 is not present in most marine magnetic profiles (W. C. Pitman III, personal commun.), and they have therefore been deleted. [For examples, see data presented in Heirtzler and others (1968), Pitman and others (1968), Ladd and others (1973), and IDOE Surveyor Seamap (1971).]

2. In joining the Blakely (1974) time scale to that of Talwani and others (1971), anomaly 4A did not appear to be in a mutually consistent position relative to anomalies 4 and 5 . We have modified the relative position of anomaly $4 \mathrm{~A}$ to make it correspond better to the observed magnetic anomaly pattern in the Southeast Indian and South Pacific Oceans.

3. After a comparison of the relative spacings of anomalies 29 to 34 in the world's ocean basins, Cande and Kristoffersen (in prep.) selected the North Pacific between lat $25^{\circ}$ and $35^{\circ} \mathrm{N}$ as a standard for the relative widths of polarity intervals by averaging the relative widths of anomalies 29 to 34 and assuming a constant rate of sea-floor spreading for the period during which the reversals were recorded by the oceanic crust.

The resulting Tertiary geomagnetic polarity scale was recalibrated by assuming a date of $3.32 \mathrm{~m}$.y. B.P. for anomaly $2 \mathrm{~A}$ (base of the Gauss normal polarity epoch; Dalrymple, 1972) and a date of 64.9 m.y. B.P. for the base of anomaly 29. The date for the latter reversal was derived from the relative position with respect to the Cretaceous-Tertiary boundary of a normally magnetized zone correlated to anomaly 29 (Lowrie and others, 1976) in a section at Gubbio, Italy. It should be noted that the rather precise date quoted for anomaly 29 reflects only its relative age with respect to the accepted age of $65 \mathrm{~m} . \mathrm{y}$. for the Cretaceous-Tertiary boundary (van Hinte, 1976; van Eysinga, 1975) and not our confidence in the absolute age of this reversal. The ages of anomalies younger than that of $2 \mathrm{~A}$ are the same as those given by Klitgord and others (1975). The dates for anomalies between 2A and 29 were determined by interpolation between the two anomalies.

The Late Cretaceous polarity sequence was calibrated in time by assuming that in the region studied by Cande and Kristoffersen (in prep.), the magnetic anomaly sequence from anomalies 23 to 34 were created at a constant rate of sea-floor spreading. We therefore applied dates to the Cretaceous sequence by extrapolating in time from the revised Tertiary time scale to anomaly 34 .

The dates and methods employed in the calibration are similar to those of Sclater and others (1974). They assigned an age of $66 \mathrm{~m} . \mathrm{y}$. B.P. for the young end of anomaly 30 on the basis of DSDP drill-hole results and assumed that the ages given by Heirtzler and others (1968) for anomalies younger than 10 m.y. B.P. (or about anomaly 5) were correct. However, since the age of anomaly 5 on the Heirtzler and others (1968) time scale was determined by extrapolation, there is nu justification for assuming that it is correctly dated for recalibration purposes. We feel that the well-determined date for anomaly $2 \mathrm{~A}$ and the recently available biostratigraphic date for anomaly 29 provide more reliable calibration points.

\section{BIOSTRATIGRAPHIC CALIBRATION}

Magnetostratigraphic techniques (for example, Ryan and others, 1974) have proved useful in directly relating magnetic polarity intervals to biostratigraphic zonations. By this method the absolute age determined for one sequence (magnetic reversal or biostratigraphic) can be used to date the other. Since ages have been estimated for both sequences, we are left to decide which dates are the more reliable. By employing the data presented above we derived a revised magnetic reversal time scale which we believe is sufficiently accurate to justify modifying the dates of the remaining Upper Cretaceous and Tertiary biostratigraphic stage boundaries, using the magnetostratigraphic correlations where available. Clearly, it is increasingly important to document carefully the method by which dates are assigned to biostratigraphy and magnetic reversal boundaries in order to avoid circular reasoning in later work.

In the time scale illustrated in Figures 1, 2, and 3, we have used as a reference the geologic time scale of van Eysinga (1975). We have modified the dates of the Neogene and Upper Cretaceous stage boundaries by applying the ages derived from our recalibrated magnetic time scale to the biostratigraphic scale, employing the correlations of Ryan and others (1974) and Alvarez and others (1977), respectively. The Paleogene stage boundaries retained the dates assigned by van Eysinga (1975). It is important to note that with the exception of the Paleogene, the revised magnetic time scale was used to assign dates to the biostratigraphic scale.

\section{COMPARISON TO DSDP DATING}

As a semi-independent test of the calibration of the revised time scale, we compared the basement ages predicted from magnetic anomaly identifications dated by the revised reversal time scale to those observed from the biostratigraphy of sediments overlying basement in various DSDP drill holes. Obviously, we must be careful in drawing conclusions from such a comparison because of the interrelationship of large sections of the biostratigraphic and magnetic reversal time scales, as discussed above. A perfect relation between observed and predicted ages may only mean that the biostratigraphic zonation has been successfully correlated to the magnetic reversal time scale, and not that the absolute dates are necessarily correct. The determination of the ages of biostratigraphic zones and magnetic anomalies ultimately depends on the extent and accuracy of radiometric dating.

Figure 4 is a modification of a figure employed by Larson and Pitman (1975). DSDP holes 332, 333, 355, 395, and 396 have been added to the plot as well as a correction of the identification of the magnetic anomaly at hole 10 . It has been shown by Kristoffersen (1976) and Cande and Kristoffersen (in prep.) that hole 10 is located near the older reversal boundary of anomaly 33, rather than on anomaly 32 , as previously identified.

In the Neogene, we would expect a perfect correlation between the magnetic and biostratigraphic basement ages, because the respective time scales are closely interrelated (Ryan and others, 1974; see also Opdyke and others, 1974; Theyer and Hammond, 1974). However, we note that two of the four biostratigraphic ages for DSDP holes near anomaly 5 appear to be older than predicted by as much as $4 \mathrm{~m}$.y. It seems unlikely that this discrepancy can be due to such a gross error in the magnetic reversal time scale, particularly in light of the apparent agreement at two of the holes near anomaly 5 and some radiometric dating of normally magnetized basaltic lava flows in Iceland correlated to anomaly 5 (McDougall and others, 1976).

The biostratigraphic zonation has not been correlated by paleomagnetic stratigraphy with the magnetic reversal time scale for Paleogene time. In this part of the time scale, the biostratigraphy of DSDP holes often indicates younger ages than the magnetic time scale would predict. The difference in age is rather consistent and may simply be explained by the law of superposition which requires the sediment to be younger than the underlying 


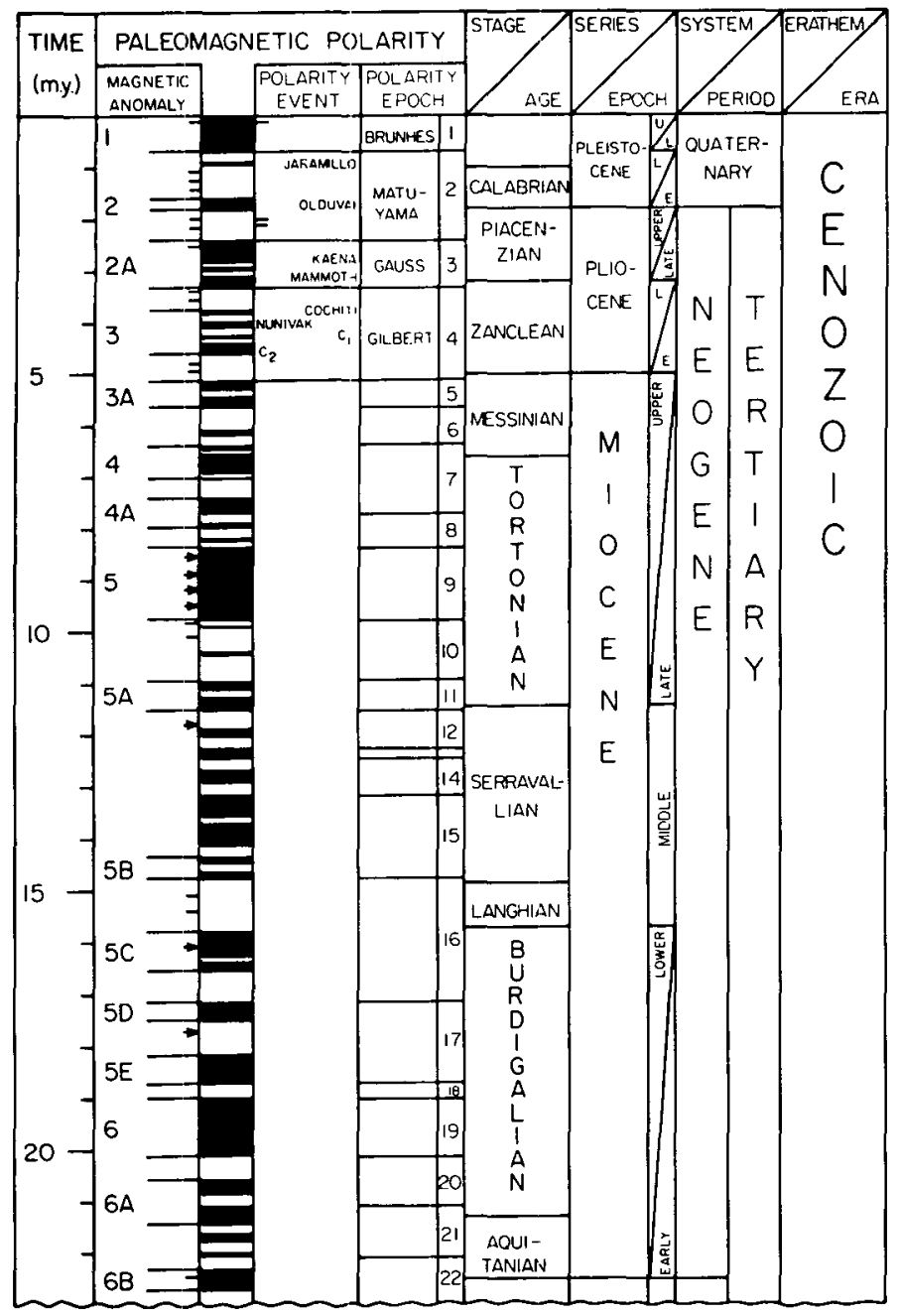

Figure 1. Revised magnetic reversal time scale and geologic time scale. Note that short arrows in the column labelled "magnetic anomaly" refer to dated events shorter than $40,000 \mathrm{yr}$ which have been removed; short lines refer to locations of additional short events or intensity fluctuations. Short lines in column labelled "polarity event" refer to possible polarity excursions. See text for details. Shaded blocks are normal polarity, open blocks are reversed polarity.

Figure 2. Revised magnetic time scale. See caption of Figure 1.

oceanic extrusive basement. Because a similar systematic discrepancy is not apparent in the Neogene, it is possible that the biostratigraphic time scale is incorrect by a small amount in the Paleogene. However, Ladd (1976) indicated changes in the relative motion of the South American and African plates during Late Cretaceous and Cenozoic time. Therefore, it is more likely that the systematic discrepancy in basement age in the Paleogene is due to small deviations from the original assumption by Heirtzler and others (1968) of a constant rate of sea-floor spreading for the South Atlantic.

Another test of the calibration of the magnetic time scale is provided by the date of the younger reversal boundary of anomaly 34 , correlated by Lowrie and others (1976) as being very close to the Campanian-Santonian boundary. A comparison of our dates for the boundaries of the Upper Cretaceous stages (Maestrichtian-Campanian-Santonian) indicates that they are 2.5

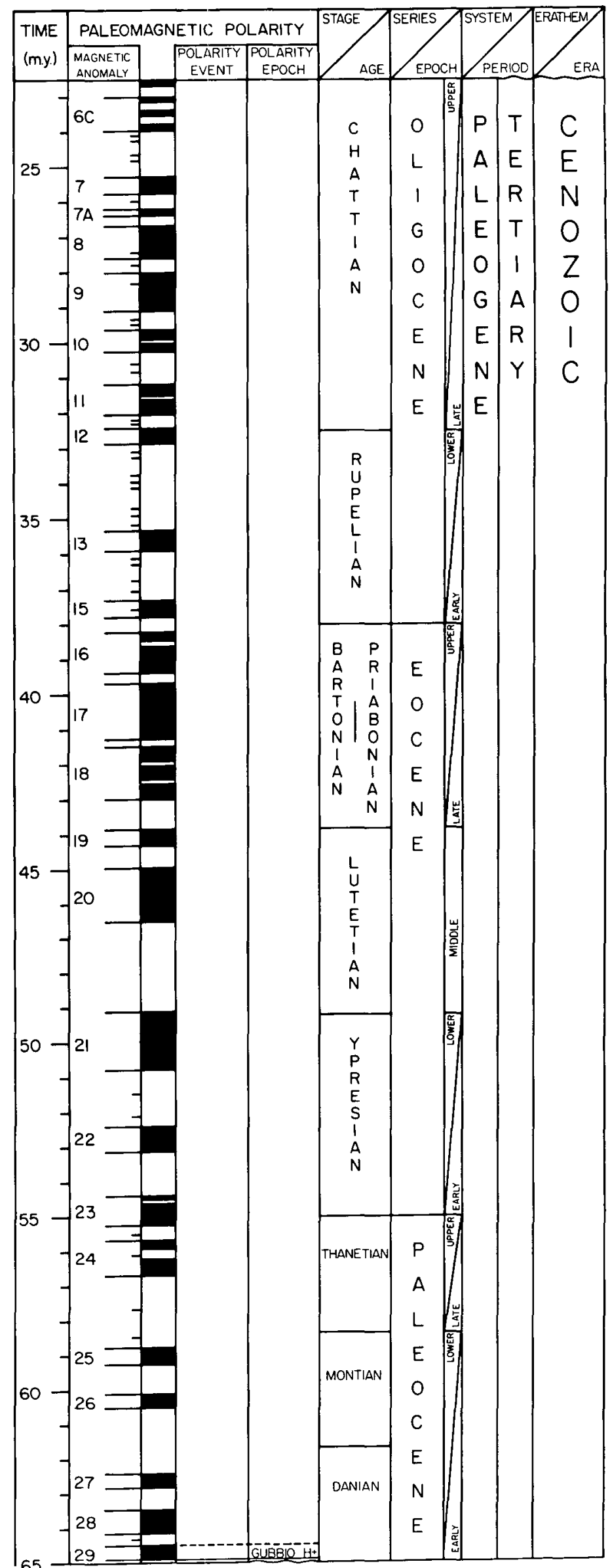




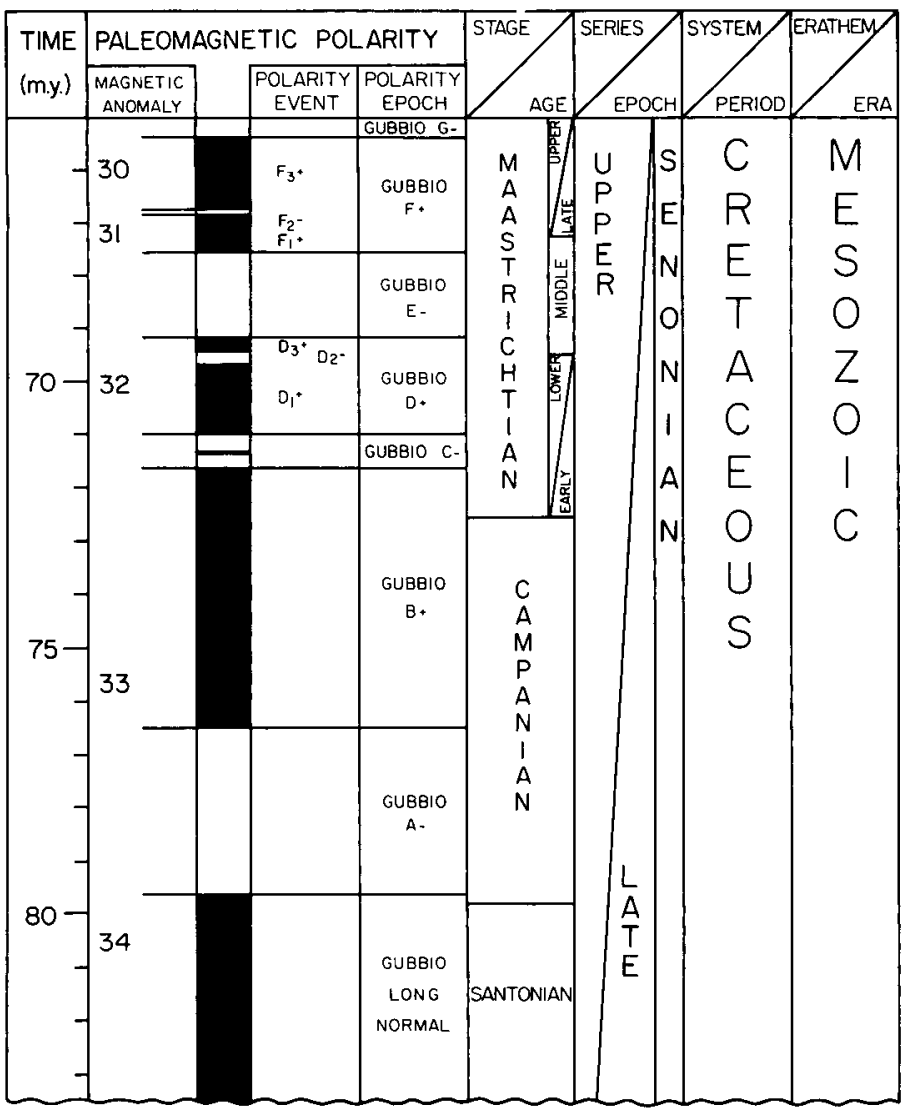

Figure 3. Revised magnetic time scale. See caption of Figure 1.

MAGNETIC ANOMALY NUMBER

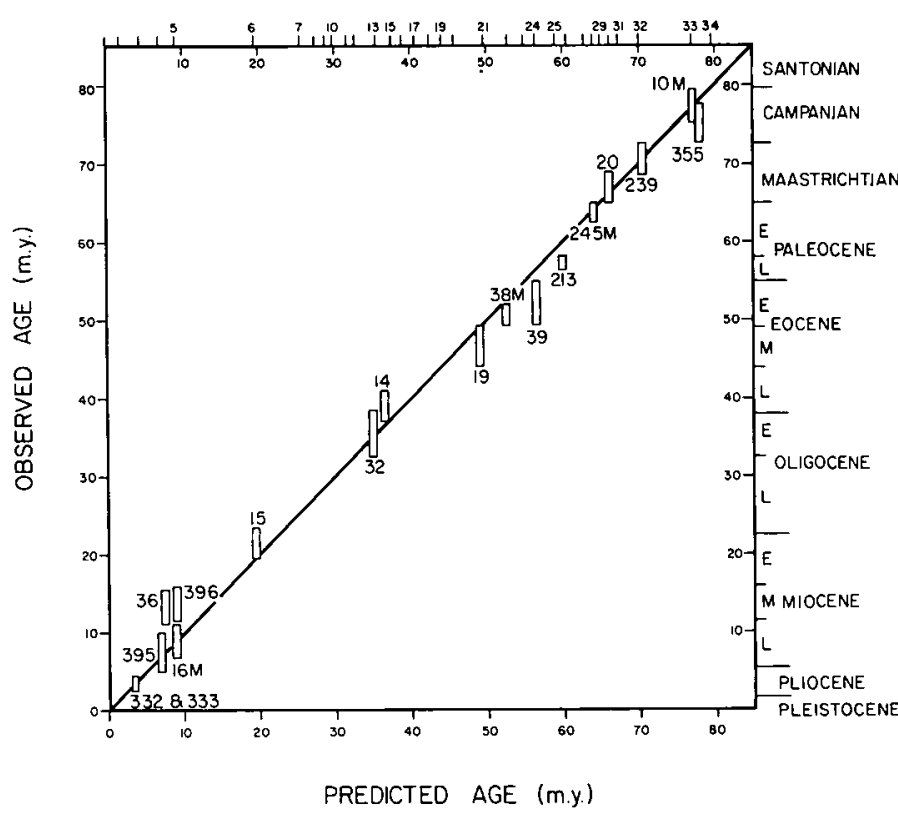

Figure 4. Comparison of age of oceanic basement as predicted by our revised magnetic reversal time scale and that observed from the biostratigrpahy of DSDP drill holes. A $45^{\circ}$ line represents theoretical line of perfect correlation between revised magnetic and biostratigraphic time scales. Revised magnetic time scale is not derived from DSDP drill-hole ages. However, Neogene and Late Cretaceous biostratigraphy has been tied to magnetic reversal pattern, as described in text. and 1.7 m.y. older, respectively, than those preferred by van Hinte (1976) on the basis of a compilation of radiometric age determinations. We feel that our dates are still well within the limits of error for the compiled radiometric ages.

Tarling and Mitchell (1976) have suggested an age of 48 m.y. for anomaly 24 on the basis of DSDP results and the apparent correlation between the age of eastern Greenland basalts and anomaly 24 . We note that there is no close age correspondence between marginal extrusive events and precise dates of early rifting. For example, the Deccan Traps were extruded at a later time than the initiation of sea-floor spreading in the Indian Ocean (Molnar and Fancheteau, 1975; McKenzie and Sclater, 1971). Furthermore, the age of the basalts of western Greenland and Baffin Island (Rosenkrantz and Pulvertaft, 1969; Clarke and Upton, 1971) appears younger than that required for the opening of the Labrador Sea, as inferred from marine magnetic anomalies (Laughton, 1971; Kristoffersen, 1976). We therefore feel that the arguments cited by Tarling and Mitchell (1976) are insufficiently strong to establish a datum point at anomaly 24 .

We further note that if the Tarling and Mitchell age for anomaly 24 is accepted, it results in a date of $92 \mathrm{~m} . \mathrm{y}$. for anomaly 34 based on the assumption of a constant sea-floor spreading rate in the North Pacific between the time of anomalies 24 and 34 . Such an old age for anomaly 34 is unlikely.

\section{TINY WIGGLES}

We have become increasingly concerned that small-scale anomalies that have been detected by various investigators (Blakely and Cox, 1972; Emilia and Heinrichs, 1972; Cande and LaBrecque, 1974; Blakely, 1974; and others) are becoming accepted as records of full-scale reversals. These features have wavelengths on the order of $20 \mathrm{~km}$ and amplitudes of 50 to $80 \gamma$ and are recognized on high-quality magnetic profiles. At the moment there is little proof that these features actually represent magnetic field reversals; indeed, they may record intensity fluctuations of the Earth's dipole field. Statistical studies of the Earth's known field behavior suggest that many additional field reversals should be present in the marine magnetic anomaly record (Harrison, 1969; Alldredge and Jacobs, 1974). However, the character and position of these small-scale magnetic anomalies would suggest a monostable field behavior should they record reversals (Cande and LaBrecque, 1974). Certainly it would be most exciting if a significant number of the features would prove to be records of intensity fluctuations, thereby allowing us to observe another type of field behavior which would give additional insight into the geomagnetic field generation mechanism. Only a detailed analysis of areas of high sea-floor spreading rate in conjunction with careful investigation of discretely sampled paleomagnetic data will determine the nature of these anomalies.

To illustrate this philosophy, we have removed from the reversal polarity column (Figs. 1, 2, 3) events that are less than $40,000 \mathrm{yr}$ in duration, because we felt that the nature of the anomaly features that these events represent were still in question. The positions of these events are indicated by arrows to the left of the polarity column. We have also added and noted the position of additional small-scale anomalies which have been recognized by various authors (Heirtzler and others, 1968; Emilia and Heinrichs, 1969; Blakely and Cox, 1972; Cande and LaBrecque, 1974; Blakely, 1974; LaBrecque and Cande, 1974; Schlich, 1975); these have been noted by short bars to the left of the reversal polarity column.

Another class of short-term paleomagnetic field behavior 
includes "polarity excursions" (Watkins, 1976) that may have been recorded in sediments and basalts. The best known examples of "polarity excursions" include the Laschamp "event" (Bonhommet and Babkine, 1967), the Blake "event" (Smith and Foster, 1969), and possibly the Reunion "events" (McDougall and Chamalaun, 1969; Grommé and Hay, 1971); we have indicated the postulated position of these as short bars to the right of the polarity column in Figure 1. It is still not clear whether "polarity excursions" represent global geomagnetic phenomena. However, it is possible that some of these short-term geomagnetic features are recorded as small-scale marine magnetic anomalies (for example, Emilia and Heinrichs, 1969, 1972).

Table 1 lists the chronological boundaries for the new time scale. We have included in this table the events of duration less than $40,000 \mathrm{yr}$ for which age boundaries have been given in the literature and which we feel are supported by sufficient data. We would like to stress, however, that these anomalies were included only because they improve the fit of synthetic magnetic anomaly pattern to the observed magnetic anomaly pattern. In most cases, these events could equally well be explained by intensity fluctuations of the Earth's magnetic field. The nature of these anomalies requires additional study. Also, the dates for the reversal boundaries are given to the nearest $10,000 \mathrm{yr}$. This precision reflects the resolution of the relative length of the polarity interval rather than the absolute dating of the reversal boundaries.

\section{REVISED SPREADING RATES}

The modification of the Heirtzler and others (1968) magnetic reversal time scale has a direct effect on sea-floor spreading rates calculated for the ocean basins. Since our principal modification was a linear readjustment of the Heirtzler and others (1968) time scale for reversals older than anomaly $2 \mathrm{~A}$ (3.32 m.y. B.P.), the result is that spreading rates calculated for ocean crust generated between anomalies $2 \mathrm{~A}$ and 29 should be increased by approximately $7 \%$. For those parts of the time scale where we have included further modifications, such as around anomaly $4 \mathrm{~A}$ and anomalies 29 to 34 , the revisions in spreading rates will be slightly different. Spreading rates in the Cretaceous magnetic quiet zone will be reduced by approximately $18 \%$ from those calculated by Larson and Pitman (1972), assuming that the date of about 108 m.y. B.P. is correct for M0 (Larson and Hilde, 1975) and using our revised date of approximately $80 \mathrm{~m}$.y. B.P. for anomaly 34 .

\section{CONCLUSION}

By incorporating an interpolation between well-dated mag. netic reversal boundaries, we have introduced a $7 \%$ correction in the dating of the Heirtzler and others (1968) time scale. We find it remarkable that the Heirtzler and others time scale achieved such an accuracy with the few data then available and with so severe an extrapolation in time.

The comparison of the revised time scale to DSDP results suggests that the original assumption of a constant sea-floor spreading rate in the South Atlantic may be slightly in error. Although the original assumption served its purpose in creating a remarkably successful magnetic reversal time scale, we feel that it is no longer necessary to satisfy this assumption in future revisions of the magnetic reversal time scale. We did not correct the small discrepancies apparent in the comparison to DSDP results, because the current accuracy of the biostratigraphic time scale is insufficient to justify any further adjustments to the magnetic time scale.
TABLE 1. REVISED MAGNETIC POLARITY TIME SCALE FOR CENOZOIC AND LATE CRETACEOUS TIME

\begin{tabular}{|c|c|c|c|}
\hline $\begin{array}{l}\text { Normal polarity } \\
\text { intervals } \\
\text { (m.y.) }\end{array}$ & $\begin{array}{c}\text { Magnetic } \\
\text { anomaly no. }\end{array}$ & $\begin{array}{l}\text { Normal polarity } \\
\text { intervals } \\
\text { (m.y) }\end{array}$ & $\begin{array}{l}\text { Magnetic } \\
\text { anomaly no. }\end{array}$ \\
\hline $0.00-0.70$ & 1 & $22.96-23.13$ & $6 C$ \\
\hline $0.89-0.95$ & & $23.25-23.49$ & $6 C$ \\
\hline $1.62-1.83$ & 2 & $23.75-23.92$ & $6 C$ \\
\hline $2.41-2.84$ & $2 A$ & $25.24-25.35$ & 7 \\
\hline $2.91-3.00$ & $2 A$ & $25.42-25.72$ & 7 \\
\hline $3.10-3.32$ & $2 A$ & $26.14-26.33$ & $7 \mathrm{~A}$ \\
\hline $3.76-3.85$ & 3 & $26.63-26.71$ & 8 \\
\hline $3.97-4.10$ & 3 & $26.79-27.54$ & 8 \\
\hline $4.24-4.31$ & 3 & $27.96-28.56$ & 9 \\
\hline $4.40-4.59$ & 3 & $28.62-29.04$ & 9 \\
\hline $5.12-5.29$ & $\Sigma A$ & $29.57-29.88$ & 10 \\
\hline $5.43-5.62$ & $3 A$ & $29.94-30.19$ & 10 \\
\hline $6.06-6.18$ & & $31.11-31.47$ & 11 \\
\hline $6.37-6.44$ & 4 & $31.53-31.96$ & 11 \\
\hline $6.51-6.90$ & 4 & $32.37-32.82$ & 12 \\
\hline $6.97-7.02$ & 4 & $35.26-35.45$ & 13 \\
\hline $7.39-7.68$ & $4 A$ & $35.52-35.86$ & 13 \\
\hline $7.87-7.95$ & $4 \mathrm{~A}$ & $37.26-37.48$ & 15 \\
\hline $8.15-8.23$ & & $37.50-37.71$ & 15 \\
\hline $8.34-8.50$ & 5 & $38.14-38.38$ & 16 \\
\hline $8.54-8.86$ & 5 & $38.55-38.84$ & 16 \\
\hline $8.87-9.15$ & 5 & $38.89-39.31$ & 16 \\
\hline $9.18-9.46$ & 5 & $39.60-40.52$ & 17 \\
\hline $9.48-9.74$ & 5 & $40.59-40.80$ & 17 \\
\hline $9.86-9.97$ & & $40.87-41.22$ & 17 \\
\hline $10.36-10.43$ & & $41.40-41.85$ & 18 \\
\hline $10.91-11.09$ & $5 A$ & $41.93-42.37$ & 18 \\
\hline $11.22-11.49$ & $5 \mathrm{~A}$ & $42.44-42.88$ & 18 \\
\hline $11.84-11.87$ & & $43.77-44.24$ & 19 \\
\hline $11.96-12.01$ & & $44.85-46.40$ & 20 \\
\hline $12.23-12.41$ & & $49.04-50.67$ & 21 \\
\hline $12.61-12.87$ & & $52.31-53.00$ & 22 \\
\hline $13.11-13.52$ & & $54.29-54.44$ & 23 \\
\hline $13.64-14.11$ & & $54.50-55.13$ & 23 \\
\hline $14.32-14.42$ & $5 B$ & $55.58-55.81$ & 24 \\
\hline $14.59-14.73$ & 58 & $56.11-56.60$ & 24 \\
\hline $15.72-16.02$ & $5 C$ & $58.67-59.16$ & 25 \\
\hline $16.06-16.24$ & $5 C$ & $59.97-60.41$ & 26 \\
\hline $16.31-16.50$ & $5 C$ & $62.30-62.72$ & 27 \\
\hline $17.11-17.45$ & 50 & $63.34-64.03$ & 28 \\
\hline $17.67-17.69$ & 50 & $64.34-64.90$ & 29 \\
\hline $18.13-18.67$ & $5 E$ & $65.37-66.76$ & 30 \\
\hline $18.95-20.07$ & 6 & $66.84-67.57$ & 31 \\
\hline $20.52-20.80$ & $6 \mathrm{~A}$ & $69.20-69.43$ & 32 \\
\hline $21.03-21.36$ & $6 A$ & $69.65-71.00$ & 32 \\
\hline $21.56-21.72$ & & $71.34-71.38$ & \\
\hline $21.92-22.02$ & & $71.62-76.48$ & 33 \\
\hline $22.24-22.65$ & $6 \mathrm{~B}$ & $79.65-108.19$ & 34 \\
\hline
\end{tabular}

Note: Short wavelength nagnetic anomalies that have been dated as events shorter than 40,000 yr have been included; however, their nature still is in question (see text). 


\section{REFERENCES CITED}

Alldredge, K. D., and Jacobs, J. A., 1974, Mortality curves for normal and reversed polarity intervals of the Earth's magnetic field: Jour. Geophys. Research, v. 79, p. 4944-4947

Alvarez, W., Arthur, M. A., Fischer, A. G., Lowrie, W., Napoleone, G., Premoli Silva, I., and Roggenthen, W. M., 1977 Upper CretaceousPaleocene magnetic stratigraphy at Gubbio, Italy: V. Type section for the Late Cretaceous-Paleocene geomagnetic reversal time scale: Geol. Soc. America Bull., v. 88, p. 383-389.

Blakely, R. J., 1974, Geomagnetic reversals and crustal spreading rates during the Miocene: Jour. Geophys. Research, v. 78, p. 8665-8686.

Blakely, R. J., and Cox, A., 1972, Evidence for short geomagnetic polarity reversals in the early Cenozoic: Jour. Geophys. Research, v. 77 , p. 7065-7072

Bonhommet, N., and Babkine, J., 1967, Magnetisme terrestre-Sur la présence d'aimantations inversées dans la Chaîne des Puys: Acad. Sci. Comptes Rendus, sér. B, v. 264, p. 92-94.

Cande, S. C., and LaBrecque, J. L., 1974, Behavior of the Earth's paleomagnetic field from small-scale marine magnetic anomalies: Nature, v. 247 , p. $26-28$.

Clarke, D. B., and Upton, B.G.J., 1971, Tertiary basalts of Baffin Island: Field relations and tectonic setting: Canadian Jour. Earth Sci. v. 8 , p. $248-258$.

Dalrymple, G. B., 1972, Potassium-argon dating of geomagnetic reversals and North American glaciations, in Bishop, W. W., and Miller, J. A., eds., Calibration of hominoid evolution: Edinburgh, Scottish Academic Press, p. 107-134.

Emilia, D. A., and Heinrichs, D. F., 1969, Ocean floor spreading: Olduvai and Gilsa events in the Matuyama epoch: Science, v. 166, p. $1267-1269$.

1972, Paleomagnetic events in the Brunhes and Matuyama epochs identified from magnetic profiles reduced to the pole: Marine Geophys. Research, v. 1, p. 436-444

Grommé, C. S., and Hay, R. L., 1971, Geomagnetic polarity epochs: Age and duration of the Olduvai normal polarity event: Earth and Planetary Sci. Letters, v. 10, p. 179-185.

Harrison, C.G.A., 1969, What is the true rate of reversals of the Earth's magnetic field?: Earth and Planetary Sci. Letters, v. 6, p. 186-188.

Heirtzler, J. R., Dickson, G. O., Herron, E. M., Pitman, W. C., III, and Le Pichon, $X ., 1968$, Marine magnetic anomalies, geomagnetic field reversals, and motions of the ocean floor and continents: Jour. Geophys. Research, v. 73, p. 2119-2136.

IDOE Surveyor Seamap, 1971, Washington, D.C., NOAA Environmental Data Service.

Klitgord, K. D., Heustis, S. P., Mudie, J. D., and Parker, R. L., 1975, An analysis of near-bottom magnetic anomalies: Sea floor spreading and the magnetized layer: Royal Astron. Soc. Geophys. Jour., v. 43 , p. $387-424$.

Kristoffersen, Y., 1976, Sea-floor spreading and the early opening of the North Atlantic: Earth and Planetary Sci. Letters (in press)

LaBrecque, J. L., and Cande, S. C., 1974, Tiny wiggles and paleomagnetic field behavior: EOS (Am. Geophys. Union Trans.), v. 55, p. 237

Ladd, J. W., 1976, Relative motion of South America with respect to North America and Caribbean tectonics: Geol. Soc. America Bull. v. 87, p. 969-976.

Ladd, J. W., Dickson, G. O., and Pitman, W. C., III, 1973, The age of the South Atlantic, in Nairn, A.E.M., and Stehli, F. G., eds., The ocean basins and margins, Vol. 1: New York, Plenum Pub. Corp., p. $555-573$.

Larson, R. L, and Hilde, T.W.C., 1975, A revised time scale of magnetic reversals for the Early Cretaceous and Late Jurassic: Jour. Geophys. Reaearch, v. 80, p. 2586-2594.

Larson, R. L., and Pitman, W. C., III, 1972, World-wide correlation of Mesozoic magnetic anomalies, and its implications: Geol. Soc. America Bull., v. 83, p. 3645-3662.

1975 , World-wide correlation of Mesozoic magnetic anomalies: Reply: Geol. Soc. America Bull., v. 86, p. 270-272.

Laughton, A. S., 1971, South Labrador Sea and the evolution of the North Atlantic: Nature, v. 232 , p. 612-617.

Lowrie, W., Alvarez, W., and Premoli-Silva, I., 1976, Late Cretaceous geomagnetic reversal sequence: EOS (Am. Geophys. Union Trans.), v. 57, p. 238 .

McDougall, I., and Chamalaun, F. H., 1969, Isotopic dating and geomagnetic polarity studies on volcanic rocks from Mauritius, Indian Ocean: Geol. Soc. America Bull., v. 80, p. 1419-1442.

McDougall, I., Watkins, N. D., Walker, G. L., and Kristjansson, L., 1976 , Potassium-argon and paleomagnetic analysis of Icelandic lava flows: Limits on the age of anomaly 5 : Jour. Geophys. Research, v. 81, p. $1505-1512$

McKenzie, D. P., and Sclater, J. G., 1971, The evolution of the Indian Ocean since the Late Cretaceous: Royal Astron. Soc. Geophys. Jour., v. 25, p. 437-528.
Molnar, P., and Francheteau, J., 1975, Plate tectonic and paleomagnetic implications for the age of the Deccan Traps and the magnetic anomaly time scale: Nature, v. 255, p. 128-130.

Opdyke, N. D., Burckle, L. H., and Todd, A., 1974, The extension of the magnetic time scale in sediments of the central Pacific Ocean: Earth and Planetary Sci. Letters, v. 22, p. 300-306.

Pitman, W. C., III, Herron, E. M., and Heirtzler, J. R., 1968, Magnetic anomalies in the Pacific and sea floor spreading: Jour. Geophys. Research, v. 73, p. 2069-2085.

Rosenkrantz, A., and Pulvertaft, T.C.R., 1969, Cretaceous-Tertiary stratigraphy and tectonics in northern west Greenland: Am. Assoc. Petroleum Geologists Mem. 12, p. 883-898.

Ryan, W. B., Cita, M. B., Rawson, M. D., Burckle, L. H., and Saito, T., 1974, A paleomagnetic assignment of Neogene stage boundaries and the development of isochronous datum planes between the Mediterranean, the Pacific and Indian Oceans in order to investigate the response of the World Ocean to the Mediterranean "salinity crisis": Riv. Italiana Paleontologia, v. 80, p. 631-688.

Schlich, R., 1975, Structure et âge de l'ocean Indien occidental: Soc. Géol. France Mém., Hors-Série 6, 103 p.

Sclater, J. G., Jarrard, R. D., McGowran, and Gardner, S., Jr., 1974, Comparison of the magnetic and biostratigraphic time scales since the Late Cretaceous, in Initial reports of the Deep-Sea Drilling Project, Vol. 22: Washington, D.C., U.S. Govt. Printing Office, p. 381-386

Smith, J. D., and Foster, J. H., 1969, Geomagnetic reversal in Brunhes normal polarity epoch: Science, v. 163, p. 565-567.

Talwani, M., Windisch, C. C., and Langseth, M. G., Jr., 1971, Reykjanes ridge crest: A detailed geophysical study: Jour. Geophys. Research, v. 76, p. 473-517.

Tarling, D. H., and Mitchell, J. G., 1976, Revised Cenozoic polarity time scale: Geology, v. 4, p. 133-136.

Theyer, F., and Hammond, S. R., 1974, Paleomagnetic polarity sequence and radiolarian zones, Brunhes to polarity epoch 20: Earth and Planetary Sci. Letters, v. 22, p. 307-319.

van Eysinga, F.W.B., compiler, 1975, Geological time table (3rd ed.): Amsterdam, Elsevier Pub. Co.

van Hinte, J. E., 1976, A Cretaceous time scale: Am. Assoc. Petroleum Geologists Bull., v. 60, p. 498-516.

Vine, F. J., and Matthews, D. H., 1963, Magnetic anomalies over oceanic ridges: Nature, v. 199, p. 947.

Watkins, N. D., 1976, Polarity subcommission sets up some guidelines: Geotimes, v. 21, p. 18-20.

\section{ACKNOWLEDGMENTS}

We thank W. Alvarez, Y. Kristoffersen, R. L. Larson, N. D. Opdyke, W. C. Pitman III, W.B.F. Ryan, R. Van der Voo, and N. D. Watkins for useful comments on the manuscript. We were stimulated in this work by the recent publication of the Magnetic Polarity Subcommission. This work was supported by Office of Naval Research Contract N00014-75-C-0210 and National Science Foundation Grants DES 7417965 and DES 75-15141. Lamont-Doherty Geological Observatory Contribution No. 2399.

MANUSCRIPT RECEIVED OCTOBER 22, 1976

MANUSCRIPT ACCEPTED MARCH 23, 1977 